\title{
Bean common bacterial blight: pathogen epiphytic life and effect of irrigation practices
}

\author{
Alireza Akhavan ${ }^{1,3^{*}}$, Masoud Bahar ${ }^{1}$, Homa Askarian${ }^{1}$, Mohammad Reza Lak ${ }^{2}$, Abolfazl Nazemi ${ }^{1}$ and Zahra Zamani
}

\begin{abstract}
In recent years, bean common bacterial blight (CBB) caused by Xanthomonas axonopodis pv. phaseoli (Xap) has caused serious yield losses in several countries. CBB is considered mainly a foliar disease in which symptoms initially appear as small water-soaked spots that then enlarge and become necrotic and usually bordered by a chlorotic zone. Xap epiphytic population community has a critical role in the development of the disease and subsequent epidemics. The epiphytic population of Xap in the field has two major parts; solitary cells (potentially planktonic) and biofilms which are sources for providing and refreshing the solitary cell components. Irrigation type has a significant effect on epiphytic population of Xap. The mean epiphytic population size in the field with an overhead sprinkler irrigation system is significantly higher than populations under furrow irrigation. A significant positive correlation between the epiphytic population size of Xap and disease severity has been reported in both the overhead irrigated $(r=0.64)$ and the furrow irrigated $(r=0.44)$ fields.
\end{abstract}

Keywords: Bean common Bacterial blight, Epiphytic life, Irrigation, Disease severity, Xanthomonas axonopodis pv. phaseoli

\section{Introduction}

Pulse legumes are a very critical protein source in many developing countries. Among them, common bean (Phaseolus vulgaris L.) is consumed worldwide as a main source of protein, particularly in most Latin-American and African countries (Reynoso-Camacho et al. 2006).

Several bacterial diseases infect common bean including common bacterial blight (CBB), halo blight, and bacterial brown spot caused by Xanthomonas axonopodis pv. phaseoli (Xap), Pseudomonas syringae pv. phaseolicola and Pseudomonas syringae pv. syringae, respectively. Although all three are destructive and economically important, CBB seems to be more widespread and causes relatively more yield loss (Hall 1994). This disease can cause up to $40 \%$ yield loss (Opio et al. 1996) and is still considered a major constraint to dry bean production in many countries and in particular Argentina, Brazil, Columbia, Mexico, Uganda, Zambia, Zimbabwe, South Africa, United States and recently Iran (Gilbertson and

\footnotetext{
* Correspondence: akhavan@ualberta.ca

${ }^{1}$ Dept. of Plant Protection, College of Agriculture, Isfahan University of

Technology, Isfahan, Iran

${ }^{3}$ Dept. of Agricultural, Food and Nutritional Science, University of Alberta,

Alberta, Canada

Full list of author information is available at the end of the article
}

Maxwell 1992; Fourie 2002; Lak et al. 2002; Harveson 2009; Zamani et al. 2011; Karavina et al. 2011). In Iran, CBB now is one of the major bean diseases in three provinces in the central part of the country (Zamani et al. 2011). It was initially reported in 2002 from bean farms with furrow irrigation system, but as a rare nondestructive disease in Markazi province in the central part of the country where 17339 hectares of pintos and kidneys bean fields were located (Lak et al. 2002). In following years, due to lack of sufficient sources of water in the province and overlooking Xap existence in the area, farmers have been encouraged to stop applying furrow irrigation and to employ overhead sprinkler irrigation due to its higher efficacy in term of water use. Overhead irrigation was widely accepted by farmers and many bean growing fields replaced furrow irrigation with overhead sprinkler. Up to 2007, large epidemics of the disease have frequently occurred in the province of Markazi leading to huge yield losses (Osdaghi et al. 2010), and typically in large fields equipped with overhead sprinkler irrigation (Figure 1).

\section{望}




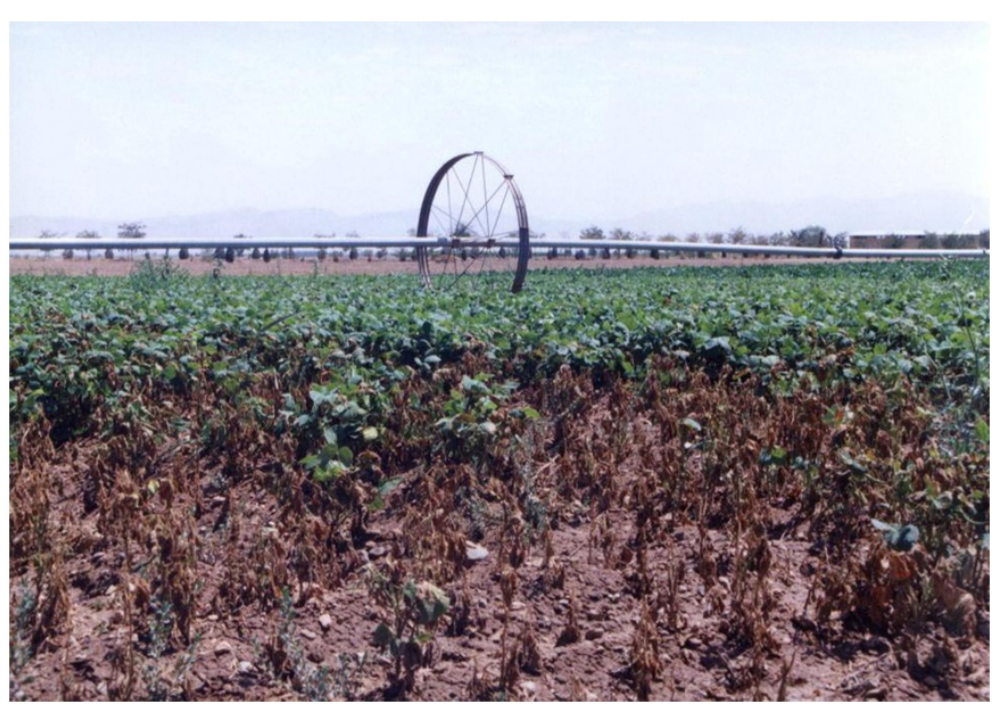

Figure 1 High disease severity showing the consequences of bacterial dispersal by overhead sprinkler irrigation, central part of Iran.

\section{Common bacterial blight symptoms}

Although CBB is considered mainly a foliar disease, symptoms can also be observed on stems, pods and seeds, symptoms initially appear as small water-soaked spots (Figure 2), which then enlarge and become necrotic and are usually bordered by a yellow zone in case of leaf spots (Figure 3) (Gilbertson and Maxwell 1992; Hall 1994; Harveson 2009). Bacterial ooze exuding from infected bean leaves can easily be observed using a compound microscope. Individual lesions may grow together causing plants to look burned, spots on pods are usually circular and brownish red, while infected seeds develop yellow to brown spots and show weak vigour and germination (Gilbertson and Maxwell 1992). Sometimes seeds have no visible symptoms and can germinate vigorously while they support large symptomless epiphytic communities of the pathogen (Figure 4) (Akhavan et al. 2009a).

\section{The causal agent of common bacterial blight}

$\mathrm{CBB}$ is caused by Xanthomonas axonopodis pv. phaseoli (also known as Xanthomonas campestris pv. phaseoli) and it's variant; Xanthomonas axonopodis pv. phaseoli var. fuscans about both, comprehensive taxonomical information have been published in many studies including Vauterin et al. (1995), Schaad et al. (2000), Vauterin et al. (2000) and Schaad et al. (2005). These two variants are identical in term of their epidemics and disease cycle but colonies of $X$. axonopodis pv. phaseoli var. fuscans are distinguished by a distinct brown pigmentation in media containing tyrosine, 2 to 9 days after inoculation (Goodwin and Sopher 1994). Typically, 3-5 days old colonies of Xap on regular media e.g. NBY (Nutrient broth 8gr, Yeast extract 0.7gr, KH2PO4 2gr, K2HPO4 0.5gr, Glucose 1gr, 1 M MgSO4 $1 \mathrm{ml}$, Agar 20gr) are convex, yellow and transparent (Figure 5), while individual cells are

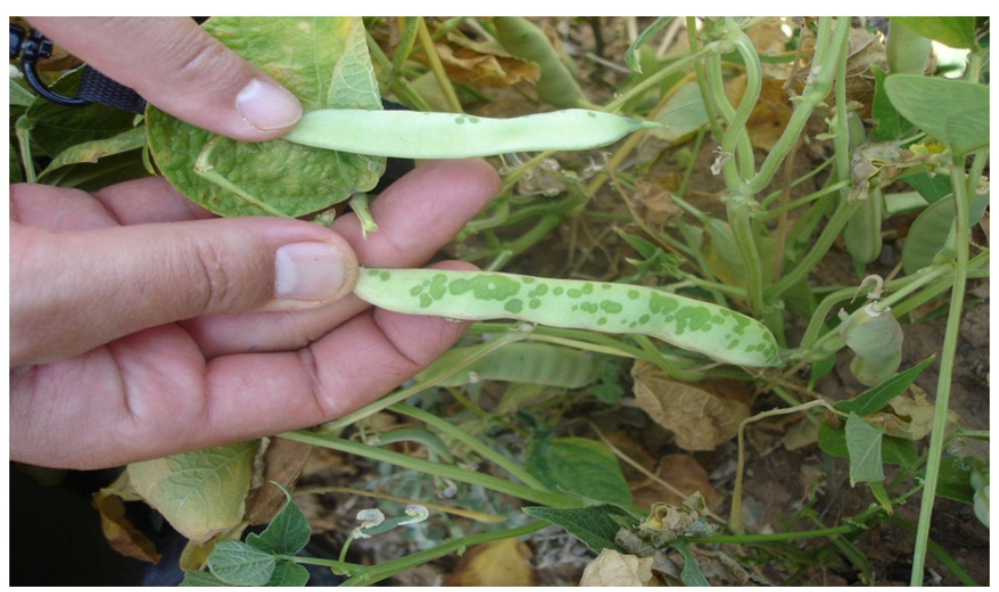

Figure 2 Initial water soaked spots on bean pods. 


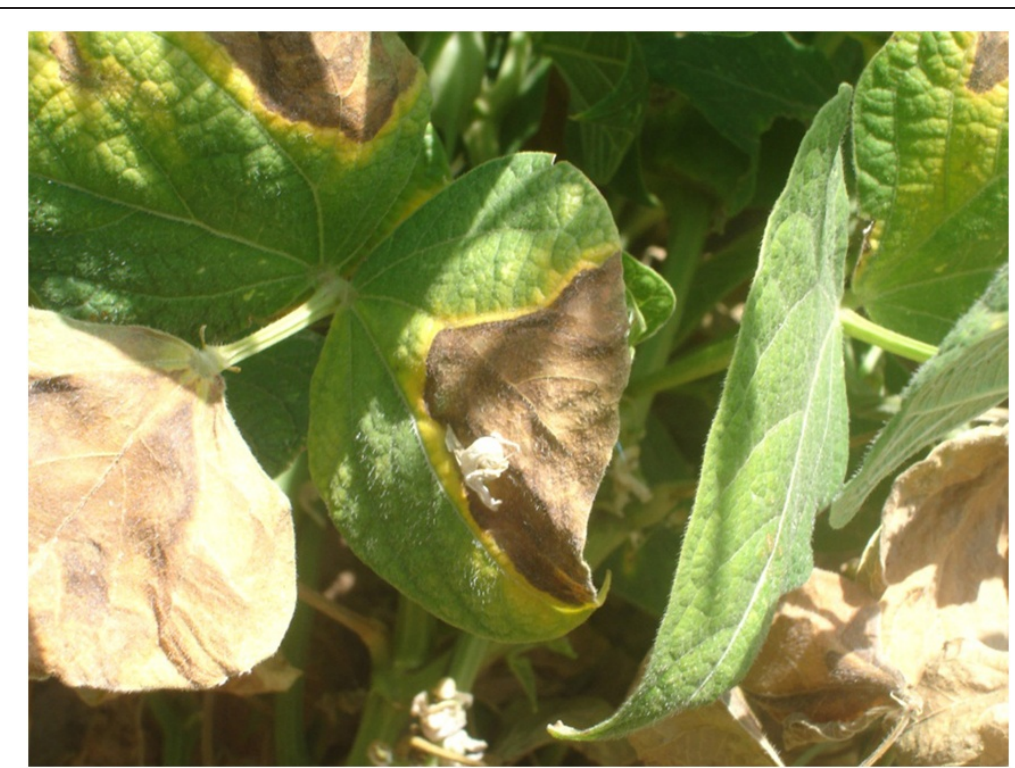

Figure 3 Enlarged necrotic lesions on bean leaves bordered by a chlorotic zone.

motile, aerobic, gram-negative, and rod-shaped with a single polar flagellum (Vidaver 1967; Schaad 2001).

\section{Plant penetration}

Cells of Xap can enter bean plants through openings such as stomata in leaves and other plant organs and through hydathodes at leaf margins, wounding of plants, such as that created by wind-blown soil particles can create pores for bacteria entry (Rudolph 1993). Bacterial cells are also readily transmitted mechanically, especially when plants are wet, while arthropods may transmit the bacterium from plant to plant (Kaiser and Vakili 1978; Lindemann and Upper 1985). The bean stem can also be penetrated in three ways: i.e., via the stomata, vascular system of the leaf and from infected cotyledons (Kaiser and Vakili 1978). Bacterial cells can also enter seeds via the vascular system or through the pedicel, while infection of the young plant occurs when internally infected seed germinates and the bacterium is transmitted

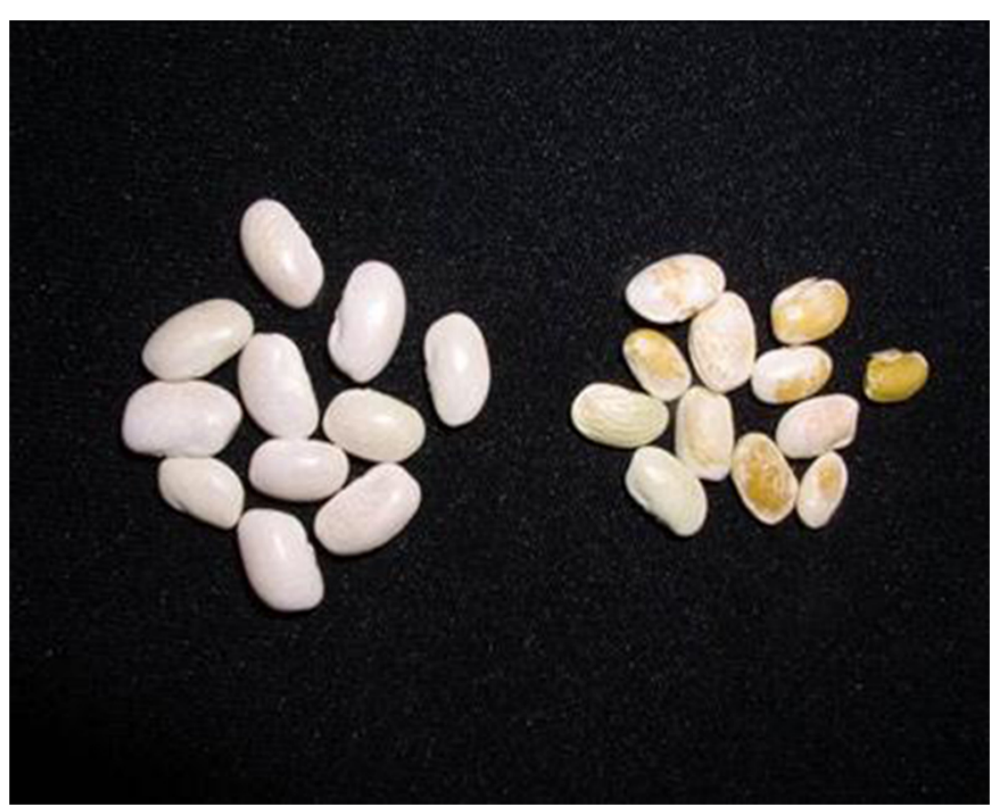

Figure 4 Infected symptomless (left) and symptomatic seeds (right). 


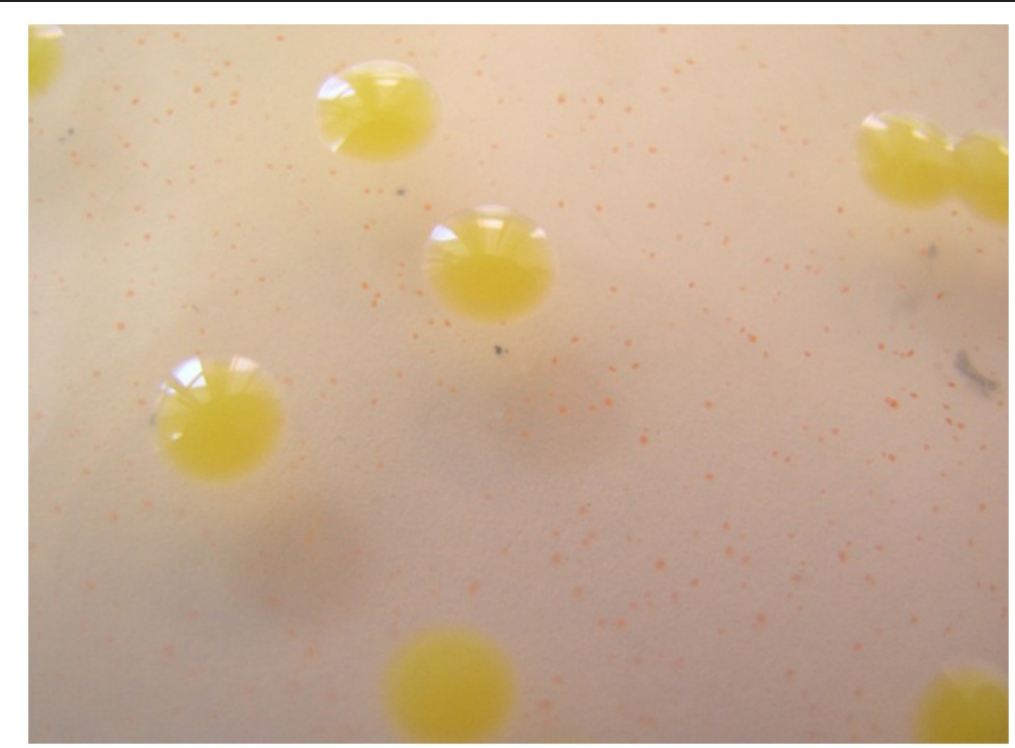

Figure 5 Bacterial colonies of Xap on Modified NBY; a new developed semi selective medium.

from the seed to seedling (Gilbertson and Maxwell 1992; Saettler 1989a).

\section{Favourable environmental conditions}

In general, Xap causes very severe disease under high rainfall and humidity and warm temperature conditions $\left(25-35^{\circ} \mathrm{C}\right)$ with maximum development occurring around $28^{\circ} \mathrm{C}$ (Gilbertson and Maxwell 1992; Saettler 1989a). Dissemination in the field is facilitated by winddriven rain, while insects, people and contaminated equipment can be considered vectors (Gilbertson and Maxwell 1992; Saettler 1989a). Overhead sprinkler irrigation like high rainfall may provide a mean for bacterial dispersal, unlike furrow irrigation (EPPO/CABI 1996; Harveson 2009). Splashing water spreads the bacterial pathogen from diseased plants to healthy plants (Lindemann and Upper 1985). However, increases in relative humidity may not facilitate CBB epidemics. For example, it has been shown that a 20 percent difference in relative humidity (53\% vs. $73 \%$ ) did not significantly affect the Xap epiphytic population size and number of bacterial spots per plant in the greenhouse under controlled conditions (Akhavan et al. 2009a).

\section{Primary inoculum}

CBB is carried both on (externally) and in (internally) seed, in bean crop debris, and epiphytically on volunteer beans and perennial alternate host plants (Gilbertson and Maxwell 1992). Among all means, contaminated seed is probably the major source of bacteria introduced into new bean fields (Gilbertson and Maxwell 1992; Saettler 1989a). Xap remains viable for years under the seed coat (Saettler 1989a;
EPPO/CABI 1996). Infected seed from a single crop may contaminate a significant area when used as a seed source; where one diseased plant in 10,000 is sufficient to cause a severe epidemic (EPPO/CABI 1996). Therefore, using pathogen-free seed is an important factor in disease management. The capability of several detection methods including Indirect ELISA, Direct PCR, Bio-PCR and Ic-PCR were compared for monitoring Xap in bean seeds (Akhavan et al. 2009b). The results indicated that sensitivity of Indirect ELISA was low and at least $10^{5}$ colonyforming unit $/ \mathrm{ml}(\mathrm{cfu} / \mathrm{ml})$ were needed as a detection threshold. In this study; the results for direct PCR were not necessarily reproducible, while Ic-PCR was found to be an expensive method. The Bio-PCR technique was considered as a reliable and specific method which was able to detect as little as $1 \mathrm{cfu} / \mathrm{ml}$ in seed extracts plated on a semi-selective medium called modified NBY (Figure 6) (Nutrient broth 8 gr, Yeast extract 0.7 gr, KH2PO4 2 gr, K2HPO4 0.5 gr, Glucose 1 gr, 1 M MgSO4 1 ml, Agar 20 gr, Cephalexin 25 mgr, 5-Fluorouracil $6 \mathrm{mgr}$, Cycloheximide $75 \mathrm{mgr}$ and Nitrofurantoin 2mgr) (Vidaver 1967; Akhavan et al. 2009b). It has also been confirmed later by other researchers that the Bio-PCR assay is suitable for sensitive and routine testing of seed samples of beans for the presence of Xap (Osdaghi et al. 2010).

Survival of the pathogen in soil or plant debris is influenced by geographical area, climate, cultural practices, host genotypes, and bacterial strains (Karavina et al. 2008). Xap may survive in crop debris in the soil from season to season (Arnaud-Santana and Pena-Matos 1991; Gilbertson et al. 1990). However, such survival might not be realistic in most 


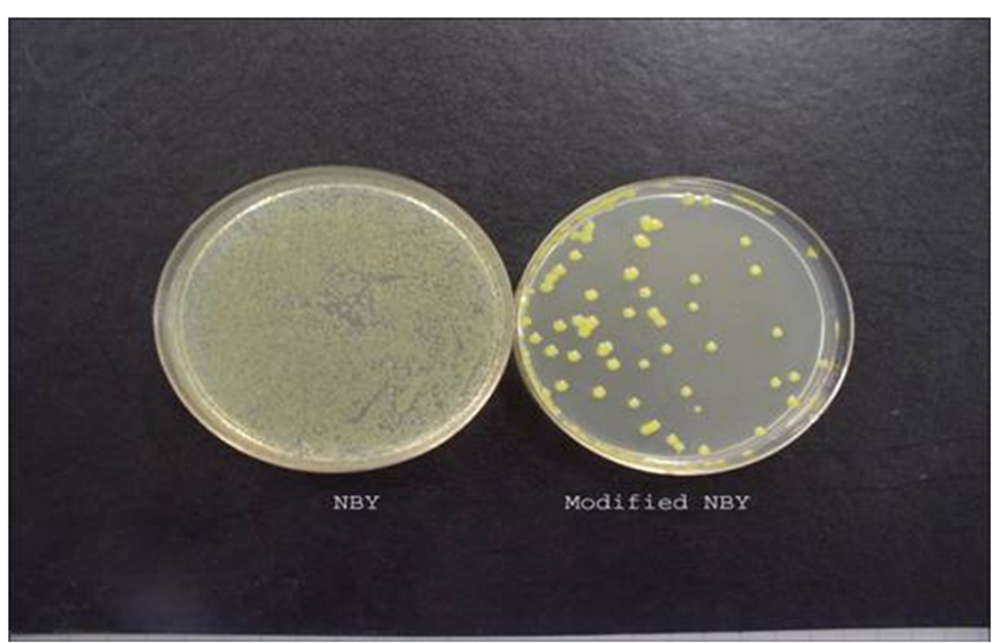

Figure 6 Comparison of NBY and Modified NBY efficiency in isolation of Xanthomonas axonopodis pv phaseoli from symptomless bean leaves when leaves were washed and the same dilution cultured on both media at the same time. Saprophytes grew on common NBY while, failed to grow on Modified NBY.

major bean growing areas of the world where the noncropping period occurs under conditions where decomposition of crop debris is rapid and almost complete. Significant populations of Xap would not be expected to survive beyond six weeks under such conditions (Pernezny and Jones 2002) while in Zimbabwe, it was shown that Xap can overwinter between crops in crop residues; therefore, residues can be considered as sources of inocula for CBB in that country (Karavina et al. 2008). Xap can also survive and multiply as an epiphyte or resident on the shoot surfaces of weed hosts, primarily members of the legume family without showing symptoms (Pernezny and Jones 2002). In the Dominican Republic, Xap has been detected on Euphorbia heterophylla (L.), Acanthospermum hispidum (D.C.) and Portulaca oleracea (L.) (Angeles-Ramos et al. 1991). In Tanzania and Uganda, Saettler reported the pathogen on Chenopodium album (L.), Solanum nigrum (L.), Echinochloa crus-galli (L.), Beta vulgaris (L.) and Amaranthus retroflexus (L.) (Saettler 1989b).

The secret life of Xanthomonas axonopodis pv. phaseoli as a foliar bacterial pathogen on leaves (symptomless colonization of leaves and biofilm formation)

A large number of foliar bacterial pathogens are able to survive and multiply on aerial parts of plants without any visible symptoms (Andrews and Harris 2000). It was demonstrated previously that Xap could survive both epiphytically and endophytically (Weller and Saettler 1980). The epiphytic population community has a very critical major role in the development of the disease and subsequent epidemics (Beattie and Lindow 1999). This symptomless period can lead to such a huge bacterial population that disease can develop later when more favorable environmental conditions occur (Wilson et al. 1999).

Xap is a seed-borne pathogen with an epiphytic symptomless population and is able to go through a long epiphytic phase on bean plants (Beattie and Lindow 1995). In general, the epiphytic population of Xap in the field has two major parts; solitary cells (potentially planktonic) and biofilms. Using ERIC fingerprinting, it has been shown for Xap that strains in the two fractions of the population are genetically identical (Jacques et al. 2005). A similar result has been demonstrated for strains of plant-associated Pseudomonas fluorescens (Boureau et al. 2004). Biofilms which are present on the surfaces of leaves are similar to those in aquatic ecosystems and hospital environments and they include a large aggregation of bacterial cells embedded in polymeric materials like extracellular polysaccharides. Comprehensive reviews on biofilm formation by plant-associated bacteria were published by Danhorn and Fuqua (2007) and Morris and Monier (2003). Among the bacteria which can form biofilms, one which is closest to Xap, is X. campestris pv. campestris in which there is a cell to cell signalling procedure. This system is coded by rpf genes cluster, which were previously known as an important cluster in the pathogenicity of bacterium (Crossman and Dow 2004). These genes have a role in production of diffusible factors like butyrolactones. The most well-known chemical in biofilm formation in many bacteria is called Acyl Homoserine Lactones (AHL), but it has not been found in the genus Xanthomonas; even though this molecule has an important role in biofilm formation of another bean bacterial pathogen; Pseudomonas syringae pv. syringae which has the same ecological cycle as the causal agent of CBB (Cha et al. 1998; Crossman and Dow 2004; Dow 
et al. 2003). Instead of AHL, butyrolactones may act as signal molecules in quorum-sensing-like systems in Xanthomonas (von Bodman et al. 2003; Jacques et al. 2005). Regarding Xap, AHL has not been found in the bacterium population; however, butyrolactones have been confirmed to have a role in biofilm formation (Jacques et al. 2005).

\section{Cell viability within biofilms and its role in providing inoculum}

The microbial epiphytic community of Xap needs to reach a threshold to be able to enter the leaves through natural openings like stomata or wounds and establish an endophytic population which leads to development of the disease (Beattie and Lindow 1999). In Michigan, this threshold has been indicated to be $2.5^{*} 10^{5}$ cfu per centimetre of bean leaves for Xap (Weller and Saettler 1980). It has been shown that the biofilm component looks stable following an initial period of growth of the Xap microbial community with population estimates of around $10^{5} \mathrm{cfu}$ per gram of bean leaves, which is likely under the population threshold needed for disease development (Jacques et al. 2005). In contrast, it seems that solitary cell components of the population are responsible for plant infection and these biofilms are a reliable source to support the development of solitary cells. Biofilms are not easily influenced by any antimicrobial factors while solitary cells can be harmed by any antimicrobial environmental factors. It is now clear that populations of solitary cells under unfavorable conditions are easily influenced by a number of abiotic and biotic factors (Monier and Lindow 2003). In general, solitary cells are sensitive to a series of environmental factors such as temperature and UV radiation and also antimicrobial chemicals. Bacteria harbored in biofilms can easily resist any copper based chemicals since the extracellular polysaccharides of the biofilm can bind the chemicals while most solitary cells are sensitive to these compounds (Costerton et al. 1995). In the same way, antibiotics may not be effective tools against biofilms. Regarding UV radiation of different wavelengths, bacteria in biofilms can be physically protected since the polysaccharides intercept the radiation and thus the embedded cells are not exposed to UV radiation (Davey and O'Toole 2000). In the case of Xap, it has been demonstrated that desiccation stress had no significant effect on biofilm population size, while solitary cell populations are drastically decreased by desiccation, overall, aggregation of bacterial cells in biofilms can protect them against unfavourable environmental conditions (Jacques et al. 2005; Amano 2010) while the same conditions can be lethal for solitary cells. A similar trend has been demonstrated for another destructive bean bacterium; $P$. syringae pv. syringae (Monier and Lindow 2003). Cells of Xap aggregated in biofilms constitute a more stable population than do solitary cell populations. In Xap, biofilm population sizes are always lower than solitary population sizes; in contrast, it was shown that solitary cell populations which provide the bacteria that enter the plant through potential pores can multiply sharply when favorable conditions occur and even right after unfavorable circumstances (Jacques et al. 2005). This scenario raises the hypothesis that biofilms are sources for providing and refreshing the solitary cell components of epiphytic communities of plant pathogenic bacteria (Boureau et al. 2004; Jacques et al. 2005). For instance, it has been demonstrated that a reduction in hydric stress, i.e. excessive moisture, allowed solitary bacterial populations to increase again and it was suggested that biofilms were reservoirs for establishing solitary cell populations (Jacques et al. 2005).

\section{The effect of irrigation system on epiphytic population size and disease severity}

In the field, rainstorms can usually be related to rises in bacterial population sizes to the threshold level with subsequent rapid disease development. The effect of rainstorms on Xap epidemics could be result of a sudden decrease of temperature or a rapid inflow of water or raindrop occurrence (Hirano et al. 1996; Jacques et al. 2005). It has been shown that epiphytic population of Xanthomonas campestris pv. vesicatoria, the cause of pepper bacterial leaf spot increased drastically following a 2-day wind-driven rain (Bernal and Berger 1996). Overhead sprinkler irrigation seems to have similar effects on bacterial population sizes as rainstorms. It has been demonstrated that the type of irrigation had a significant effect on epiphytic populations of Xap. Although the bacterial populations were the same size at the beginning, the mean epiphytic population size in the field with an overhead sprinkler irrigation system was $1.04 * 10^{6}$ colony forming unit per each squared centimeter of bean leaves $(\mathrm{cfu} / \mathrm{cm} 2)$ while for a furrow irrigation system, population size was $4.89 * 10^{4} \mathrm{cfu} / \mathrm{cm}^{2}$ (Akhavan et al. 2009a).

It seems that overhead irrigation systems favour pathogen dissemination from colonized to healthy leaves as the key factor in increasing the total field epiphytic population size. In terms of multiplication, overhead irrigation provides a layer of water on the host plant surface, which results in an ideal multiplication site for the microbial planktonic community on plant leaves. Studies of other foliar bacterial pathogens have also confirmed that epiphytic population size can increase when the plant surfaces are wet (Beattie and Lindow 1995). The presence of a film of water also helps to promote nutrient release from plant leaves, which can enhance the availability of nutrient sources for the epiphytic bacterial community (Hirano and Upper 1983). Plant age by itself was found to have no effect on epiphytic Xap populations (Karavina et al. 2011). For Xap, it was indicated in another study that 10 
percent of the total epiphytic population size particularly the solitary cells can move easily by rain (Mabagala 1997). In general, we can conclude that sprinkler irrigation has effects similar to rain; it can lower leaf and canopy temperature, increase relative humidity, and may prolong dew periods; it can enhance splash dispersal drastically; and it may remove cells from the atmosphere and deposit them on susceptible plant surfaces. However, one also has to notice the association of favourable weather conditions and the frequency of irrigation. The use of furrow rather than overhead irrigation systems in low rainfall areas has been found to restrict the spread of splash-dispersed pathogens (Baker 1980), and furrow irrigation is recommended in these areas to restrict pathogen spread (Icishahayo et al. 2007). It has been demonstrated that with furrow irrigation, the population of Xap on bean leaves only increased up to just 10 days after the third trifoliate leaf unfolded (V4) (Fernandez et al. 1986) following an initial inoculation at the second trifoliate stage leading to the appearance of symptoms on a few bean leaves. Infected bean leaves then senesced and even fell off of the plants before the "beginning bloom stage", while the remaining plant leaves looked almost normal. In contrast, with overhead sprinkler irrigation; Xap populations increased up to 40 days, which coincided with the "pod filling stage" (Figure 7), while eventually destroying almost the whole bean crop (Akhavan et al. 2009a).

It has been revealed that irrigation type significantly influenced disease severity. Disease severity means were 5.8 and 2.8 in fields with overhead sprinkler irrigation and furrow irrigation, respectively using the standard system for the evaluation of bean germplasm with 1 as "no visible disease symptoms" and 9 as "very severe disease symptoms"(Schoonhoven and Pastor-Corrales 1994;

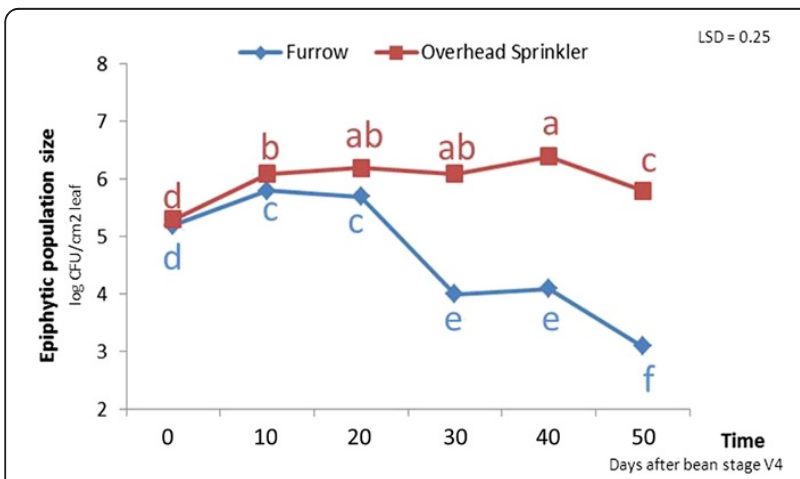

Figure 7 In furrow irrigation, Xap population size $(\log \mathrm{cfu} / \mathrm{cm} 2$ leaf) increased up to just 10 days after the third trifoliate leaf unfolded (V4) following an initial inoculation at the second trifoliate stage while for overhead sprinkler irrigation, the population size increased up to $\mathbf{4 0}$ days. Means with different letters are significantly different. The experiments were conducted in two different fields in the same research farm using a randomized complete block design with eight replicates in Arak, Iran in 2005.
Akhavan et al. 2009a). In addition to dispersing bacterial cells and helping them to reach healthy plants as the key factor, and promoting release of leaf nutrients to the microbial community, overhead sprinkler irrigation can generate a film of water over the leaf surface including stomata, providing the symptomless epiphytic populations with a bridge to enter the plant resulting in disease symptoms development (Carvalho et al. 2011). Previously, it has also been shown that Asiatic citrus canker was more severe when applying overhead irrigation system which also increased the incidence of this disease caused by Xanthomonas axonopodis pv. citri (Pruvost et al. 1999). In contrast, Wheeler et al. (2007) showed that overhead irrigation increased disease incidence of cotton bacterial blight by Xanthomonas axonopodis pv. malvacearum in a partially resistant cultivar; PM 2200 RR compared with drop hoses, while irrigation method did not influence disease incidence for the susceptible cultivar; PM 2326RR.

Akhavan et al. (2009a) showed that the interaction of irrigation system and time was significant for disease severity. Within-furrow irrigation the $\mathrm{CBB}$ disease severity index had not changed between the R6 (full flowering) to R8 (pod filling) bean growth stages, but in contrast it had significantly increased during the same period in the field using an overhead sprinkler irrigation system (Figure 8).

\section{Epiphytic population size, disease severity and yield correlations: a brief conclusion}

A significant $(\mathrm{P}<0.05)$ positive correlation between the epiphytic population size of Xap and disease severity in both the overhead irrigated field $(r=0.64)$ and the furrow irrigated field $(r=0.44)$ has been reported (Akhavan

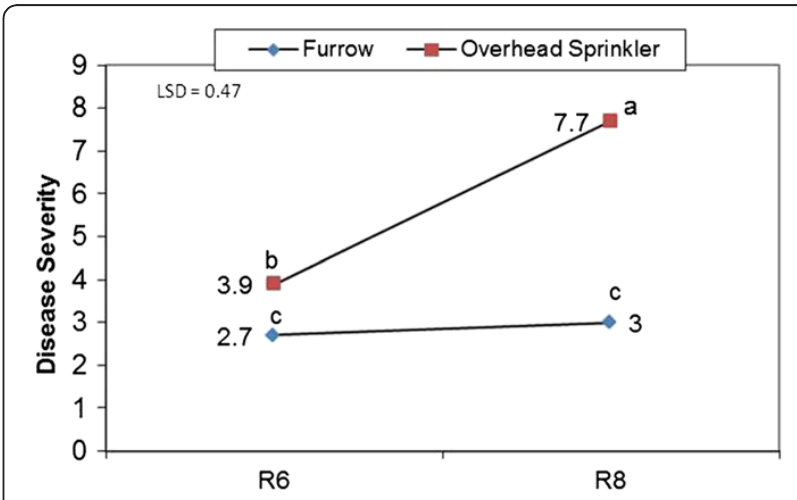

Figure 8 The interaction of irrigation system and time on CBB disease severity. With furrow irrigation, the CBB severity index did not change between the R6 (full flowering) and R8 (pod filling) bean growth stages. In contrast, CBB severity significantly increased from the R6 and R8 bean growth stages for the field using an overhead sprinkler irrigation system. The experiments were conducted in two different fields in the same research farm using a randomized complete block design with eight replicates in Arak, Iran in 2005. 
et al. 2009a). The reason for the higher correlation coefficient with the overhead sprinkler irrigation system can be due to the effect of this type of irrigation on bacterial penetration to interior leaf spaces and subsequent development of disease. Similar results have been reported by other studies on the effect of windblown rain fall (Gilbertson and Maxwell 1992). Significant positive correlations between bacterial populations and disease severity have also been shown in other studies. For example, the epiphytic population of $X$. campestris pv. vesicatoria, the causal agent of tomato bacterial spot, was positively correlated with plant defoliation as a result of disease development (McGuire et al. 1991). Previously, Lindemann et al. (1984) also showed that the severity of brown spot of bean was correlated more consistently with epiphytic Pseudomonas syringae pv. syringae population sizes than with disease incidence. A significant $(\mathrm{P}<0.05)$ negative correlation between disease severity and seed yield per plant for both the furrow irrigated field $(r=-0.59)$ and the overhead sprinkler irrigated field $(\mathrm{r}=-0.68)$ has also been reported (Akhavan et al. 2009a). Furthermore, in both systems, there was a significant $(\mathrm{P}<0.05)$ negative correlation between disease severity and total seed yield, but the coefficient correlation was higher under overhead sprinkler irrigation $(\mathrm{r}=-0.83)$ compared to furrow irrigation $(\mathrm{r}=-0.66)$. This difference is likely due to more severe disease in the field under overhead sprinkler irrigation system. Since the only difference between the two fields was the type of irrigation method, it can be interpreted that the overhead sprinkler system provided several factors that encouraged epiphytic populations to increase and to establish an endophytic population of Xap. Overhead irrigation can provide an ideal multiplication site, i.e. a thin layer or film of water on the bean leaf surface, while also disseminating the pathogen from diseased to healthy plants. Overhead sprinkler irrigation may also help the epiphytic population of Xap to establish an aggressive endophytic population by facilitating the entry of bacterial cells through leaf openings followed by symptom development.

\footnotetext{
Abbreviations

CBB: Common bacterial blight; Xap: Xanthomonas axonopodis pv. phaseoli; cfu: Colony-forming unit.
}

\section{Competing interests}

The authors declare that they have no competing interests.

\section{Authors' contributions}

All authors were involved in the preparation of the manuscript draft, and read and approved the final manuscript.

\section{Acknowledgments}

We wish to express our appreciation to Mr. Mojtaba Emam-Jomeh, Mr. Valiollah Rahmati and Mr. Esmaeel Azizi for excellent field and technical assistance. This work was funded by a grant from the graduate school of Isfahan University of Technology in Iran.

\section{Author details}

'Dept. of Plant Protection, College of Agriculture, Isfahan University of Technology, Isfahan, Iran. ${ }^{2}$ Plant Pests and Diseases Res. Division, Agricultural and Natural Resources Res. Center, Arak, Iran. ${ }^{3}$ Dept. of Agricultural, Food and Nutritional Science, University of Alberta, Alberta, Canada.

Received: 10 September 2012 Accepted: 4 February 2013

Published: 8 February 2013

\section{References}

Akhavan A, Bahar M, Saeidi G, Lak MR (2009a) Factors affecting epiphytic population of Xanthomonas axonopodis pv. phaseoli in epidemiology of bean common blight. J Sci \& Technol Agric \& Natur Resour 13:265-277

Akhavan A, Bahar M, Saeidi G, Lak MR (2009b) Comparison of different methods for detection of Xanthomonas axonopodis pv. phaseoli in bean seeds. Iran J Plant Pathol 45:1-7

Amano A (2010) Bacterial adhesins to host components in periodontitis. Periodontol 2000 2000(52):12-37

Andrews JH, Harris RF (2000) The ecology and biogeography of microorganisms on plant surface. Annu Rev Phytopathol 38:145-180

Angeles-Ramos R, Vidaver AK, Flynn P (1991) Characterization of epiphytic Xanthomonas campestris pv. phaseoli and pectolytic Xanthomonads recovered from symptomless weeds in the Dominican republic. Phytopathol 81:677-681

Arnaud-Santana E, Pena-Matos E (1991) Longevity of Xanthomonas campestris pv. phaseoli in naturally infested dry bean (Phaseolus vulgaris) debris. Plant Dis 75:952-953

Baker KF (1980) Seed pathology. In: Kozlowski TT (ed) Seed biology, vol 2. Academic Press, New York, pp 317-416

Beattie GA, Lindow SE (1995) The secret life of foliar bacterial pathogens on leaves. Annu Rev Phytopathol 33:145-172

Beattie GA, Lindow SE (1999) Bacterial colonization of leaves: a Spectrum of strategies. Phytopathol 89:353-359

Bernal RF, Berger RD (1996) The spread of epiphytic populations of Xanthomonas campestris pv. vesicatoria on pepper in the field. J Phytopathol 144:479-484

Boureau T, Jacques M-A, Berruyer R, Dessaux Y, Dominguez H, Morris CE (2004) Comparison of the phenotypes and genotypes of biofilm and solitary epiphytic bacterial populations on broad-leaved endive. Microb Ecol 47:87-95

Carvalho AO, Da Cunha M, Rodrigues R, Sudré CP, Santos IS, Fernandes KVS, Rabelo GR, Gomes VM (2011) Ultrastructural changes during early infection of Vigna unguiculata and Phaseolus vulgaris leaves by Xanthomonas axonopodis pv. phaseoli and an unexpected association between chloroplast and mitochondrion. Acta Physiologiae Plantarum 33:2025-2033

Cha C, Gao P, Chen YC, Shaw PD, Farrand SK (1998). Production of acylhomoserine lactone quorum sensing signals by gram-negative plantassociated bacteria. Mol. Plant-Microbe Interact. 11:1119-1129.

Costerton JW, Lewandowski Z, Caldwell DE, Korber DR, Lappinscott HM (1995) Microbial biofilms. Annu Rev Microbiol 49:711-745

Crossman L, Dow JM (2004) Biofilm formation and dispersal in Xanthomonas campestris. Microbes Infect 6:623-629

Danhorn T, Fuqua C (2007) Biofilm Formation by Plant-Associated Bacteria. Annu Rev Microbiol Vol 61:401-422

Davey ME, O'Toole GA (2000) Microbial biofilms: from ecology to molecular genetics. Microbiol Mol Biol Rev 64:847-867

Fernandez F, Gepts P, Lopez M (1986) Stages of development of the common bean plant. Centro Internacional de Agricultura Tropical (CIAT), Cali, Colombia

Fourie D (2002) Distribution and severity of bacterial diseases on dry beans (Phaseolus vulgaris L) in South Africa. J Phytopathol 150(4-5):220-226

Gilbertson RL, Rand RE, Hagedorn DJ (1990) Survival of Xanthomonas campestris pv. phaseoli and pectolytic strains of $X$. campestris in bean debris. Plant Dis 74:322-327

Gilbertson RL, Maxwell DP (1992) Common bacterial blight of bean. In: Chaube HS, Kumar J, Mukhopadhyay AN, Singh US (eds) Plant diseases of international importance, Vol II Prentice Hall, Englewood Cliffs, New Jersey., pp 18-39

Goodwin PH, Sopher CR (1994) Brown pigmentation of Xanthomonas campestris pv. phaseoli associated with homogentisic acid. Can J Microbiol 40:28-34 
Hall R (1994) Compendium of bean diseases. APS Press, St. Paul, Minnesota Harveson RM, (2009) Common bacterial blight of dry beans in Nebraska. http:// ianrpubs.unl.edu/epublic/live/g1956/build/g1956.pdf.

Hirano SS, Baker LS, Upper CD (1996) Raindrop momentum triggers growth of leaf-associated populations of Pseudomonas syringae on field-grown snap bean plants. Appl Environ Microbiol 62:2560-2566

Hirano SS, Upper C (1983) Ecology and epidemiology of foliar bacterial plant pathogens. Annu Rev Phytopathol 21:243-269

Icishahayo D, Ngadze E, Mashingaidze AB, Sibiya J, Manyangarirwa W, Chipindu B (2007) Effect of irrigation and planting date on common bean seed quality and health African Crop Science Conference Proceedings. 8:479-487

Jacques M-A, Josi K, Darrasse A, Samson R (2005) Xanthomonas axonopodis pv. phaseoli var. fuscans is aggregated in stable biofilm population sizes in the phyllosphere of field-grown beans. Appl Environ Microbiol 71(4):2008-2015

Kaiser WJ, Vakili NG (1978) Insect transmission of pathogenic Xanthomonads to bean and cowpea in Puerto Rico. Phytopathol 68:1057-1036

Karavina C, Tigere TA, Chihiya J (2008) The contribution of soil and crop debris inocula to the outbreak of bacterial common blight in field beans (Phaseolus vulgaris L.) under Zimbabwean conditions. Journal of Sustainable Development in Africa 10(No3):221-233

Karavina C, Mandumbu R, Parwada C, Zivenge E (2011) Epiphytic Survival of Xanthomonas axonopodis pv. phaseoli (E. F SM) Journal of Animal \& Plant Sciences 9(2):1161-1168

Lak MR, Shamsbakhsh M, Bahar M (2002) Identification of the bacterial agent of bean leaf and pod blight in Markazi province. J Sci \& technol Agric \& natur Rsour 6:231-243

Lindemann J, Arny DC, Upper CD (1984) Use of an apparent infection threshold population of Pseudomonas syringae to predict incidence and severity of brown spot of bean. Phytopathol 74(11):1334-1339

Lindemann J, Upper CD (1985) Aerial dispersal of epiphytic bacteria over bean plants. Appl Environ Microbiol 50(5):1229-1232

Mabagala RB (1997) The effect of population of Xanthomonas campestris pv. phaseoli in bean reproductive tissues on seed infection of resistant and susceptible bean genotypes. Eur J Plant Pathol 103:175-181

Dow JM, Crossman L, Findlay K, He YQ, Feng JX, Tang JL (2003) Biofilm dispersal in Xanthomonas campestris is controlled by cell-cell signaling and is required for full virulence to plants. Proc Natl Acad Sci 100:10995-11000

McGuire RG, Jones JB, Scott JW (1991) Epiphytic population of Xanthomonas campestris pv. vesicatoria on tomato cultigens resistant and susceptible to bacterial spot. Plant Dis 75:606-609

Monier JM, Lindow SE (2003) Differential survival of solitary and aggregated bacterial cells promotes aggregate formation on leaf surfaces. Proc Natl Acad Sci 100:15977-15982

Morris CE, Monier JM (2003) The ecological significance of biofilm formation by plant-associated bacteria. Annu Rev Phytopathol 41:429-453

EPPO/CABI (1996) Xanthomonas axonopodis pv. phaseoli. http:/www.eppo.int/ QUARANTINE/bacteria/Xanthomonas_phaseoli/XANTPH_ds.pdf.

Opio AF, Allen DJ, Teri JM (1996) Pathogenic variation in Xanthomonas campestris pv. phaseoli, the causal agent of common bacterial blight in Phaseolus beans. Plant Pathol 45:1126-1133

Osdaghi E, Shams-bakhsh M, Alizadeh A, Lak MR (2010) Study on common bean seed lots for contamination with Xanthomonas axonopodis pv. phaseoli by BIO-PCR technique. Journal of Agricultural Technology 6(3):503-513

Pernezny K, Jones JB (2002) Common bacterial blight of snap bean in Florida. University of Florida Cooperative Extension Service Plant Path Fact Sheet No 62

Pruvost O, Gottwald TR, Brocherieux C (1999) The effect of irrigation practices on the spatio-temporal increase of Asiatic citrus canker in simulated nursery plots in Reunion Island. Eur J Plant Pathol 105(1):23-37

Reynoso-Camacho R, Ramos-Gomez M, Loarca-Pina G (2006) Bioactive components in common beans (Phaseolus vulgaris $\mathrm{L}$ ). Advances in Agricultural and Food Biotechnology, pp 217-236

Rudolph K (1993) Infection of the plant by Xanthomonas. In: Swings JG, Civerolo EL (eds) Xanthomonas. Chapman \& Hall, London, pp 193-264

Saettler AW (1989a) Common bacterial blight. In: Schwartz HF, Pastor-Corrales MA (eds) Bean production problems in the tropics. Centro Internacional de Agricultura Tropical, Cali, Colombia, pp 261-283

Saettler AW (1989b) Assessment of yield loss caused by common blight of beans in Uganda. Annual Report of the Bean Improvement Cooperative 35:113-114

Schaad NW (2001) Initial identification of common genera. In: Schaad NW, Jones JB, Chun W (eds) Plant pathogenic bacteria. APS Press, St. Paul, Minnesota, pp 1-16
Schaad NW, Postnikova E, Lacy GH, Sechler A, Agarkova I, Stromberg PE, Stromberg VK, Vidaver AK (2005) Reclassification of Xanthomonas campestris pv. citri (ex Hasse 1915) Dye 1978 forms A, B/C/D, and E as X. smithii subsp citri (ex Hasse) sp nov nom. rev. comb. nov., X. fuscans subsp aurantifolii (ex Gabriel 1989) sp nov nom. rev. comb. nov., and X. alfalfae subsp citrumelo (ex Riker and Jones) Gabriel et al., 1989 sp nov nom. rev. comb. nov.; X. campestris pv. malvacearum (ex Smith 1901) Dye 1978 as X. smithii subsp smithii nov comb. nov nom. nov.; $X$. campestris pv. alfalfae (ex Riker and Jones, 1935) Dye 1978 as X. alfalfae subsp alfalfae (ex Riker et al., 1935) sp nov nom. rev.; and "var. fuscans" of X. campestris pv. phaseoli (ex Smith, 1987) Dye 1978 as X. fuscans subsp fuscans sp nov. Syst Appl Microbiol 28:494-518

Schaad NW, Vidaver AK, Lacy GH, Rudolph K, Jones JB (2000) Evaluation of proposed amended names of several pseudomonads and xanthomonads and recommendations. Phytopathol 90:208-213

Schoonhoven AV, Pastor-Corrales MA (1994) Standard system for the evaluation of bean germplasm. Centro Internacional de Agricultura Tropical, Cali, Colombia

Vauterin SL, Hoste B, Kersters K, Swings J (1995) Reclassification of Xanthomonas. Int. J. Syst. Bacteriol 45:472-489

Vauterin L, Rademaker JLW, Swings J (2000) Synopsis on the taxonomy of the genus Xanthomonas. Phytopathol 90:677-682

Vidaver AK (1967) Synthetic and complex media for rapid detection of fluorescence of phytopathogenic pseudomonads: effect of the carbon source. Appl Microbiol 15:1523-1524

von Bodman SB, Dietz Bauer W, Coplin DL (2003) Quorum sensing in plantpathogenic bacteria. Annu Rev Phytopathol 41:455-482

Weller DM, Saettler AW (1980) Colonization and distribution of Xanthomonas phaseoli and Xanthomonas phaseoli var. fuscans in field-grown navy beans. Phytopathol 70:500-506

Wheeler TA, Sagaram US, Schuster GL, Gannaway JR (2007) Identification of factors that influence screening for bacterial blight resistance. Journal of Cotton Science 11:91-97

Wilson M, Hirano SS, Lindow SE (1999) Location and survival of leaf-associated bacteria in relation to pathogenicity and potential for growth within the leaf. Appl Environ Microbiol 65(4):1435-1443

Zamani Z, Bahar M, Jacques M-A, Lak MR, Akhavan A (2011) Genetic diversity of the common bacterial blight pathogen of bean, Xanthomonas axonopodis pv. phaseoli, in Iran revealed by rep-PCR and PCR-RFLP analyses. World J Microbiol Biotechnol 27:2371-2378

doi:10.1186/2193-1801-2-41

Cite this article as: Akhavan et al:: Bean common bacterial blight: pathogen epiphytic life and effect of irrigation practices. SpringerPlus 2013 2:41.

\section{Submit your manuscript to a SpringerOpen ${ }^{\circ}$ journal and benefit from:}

- Convenient online submission

- Rigorous peer review

- Immediate publication on acceptance

- Open access: articles freely available online

- High visibility within the field

- Retaining the copyright to your article

Submit your next manuscript at $>$ springeropen.com 